\title{
PENINGKATAN KUALITAS BACAAN KITAB KUNING BAGI SANTRI DESA DI PONDOK PESANTREN WALI SONGO PLERET BANTUL
}

\author{
Muhammad Khabibullah \\ Pondok Pesantren Wali Songo Pleret Bantul, Yogyakarta, Indonesia \\ §muhammadhabib0707@gmail.com \\ Ahmad Shofiyuddin Ichsan \\ Institut Ilmu Al Qur'an An Nur Yogyakarta, Indonesia \\ Muh. Subhan Ashari \\ Institut Ilmu Al Qur'an An Nur Yogyakarta, Indonesia
}

\begin{abstract}
Abstrak
Penelitian ini mengungkap bagaimana meningkatkan bacaan kitab kuning melalui metode sorogan terhadap santri desa di Pondok Pesantren Wali Songo Pleret Bantul dan apa saja faktor dan penghambat dalam penerapan metode sorogan untuk meningkatkan bacaan kitab kuning santri desa di pesantren tersebut. Penelitian ini merupakan penelitian deskriptif kualitatif, sedangkan teknik pengumpulan data menggunakan wawancara, observasi dan dokumentasi. Hasil penelitian menunjukkan bahwa upaya ustaz dalam meningkatkan kemampuan membaca kitab kuning sangat efektif. Hal ini didasari oleh tujuan pokok metode sorogan yaitu meningkatkan kualitas membaca, kepemahaman isi, dan dapat mengungkapkan isi bacaan. Tidak hanya itu, peningkatan itu terlihat juga dari banyaknya faktor pendukung dan minimnya faktor penghambat.
\end{abstract}

Kata Kunci: Kitab Kuning, Santri Desa, Sorogan, Pondok Pesantren

\begin{abstract}
This research reveals how to improve reading of 'the yellow book' through the sorogan method for village students at Pesantren Wali Songo Pleret, Bantul and what are the factors and obstacles in the application of the sorogan method to improve reading of 'the yellow book' of village students in the pesantren. This research is qualitative descriptive research, while the data collection techniques used interviews, observation and documentation. The results showed that Ustaz's efforts in improving the ability to read 'the yellow book' were considered very effective. This is based on the main purpose of the sorogan method, namely improving reading quality, understanding content, and being able to reveal the content of reading. Not only that but the increase can also be seen from the many supporting factors and the lack of inhibiting factors.
\end{abstract}

Keywords: Yellow Book, Village Students, Sorogan Method, Islamic Boarding School

\section{Pengantar}

Pendidikan mempunyai banyak tujuan dan yang termasuk salah satu tujuan dari pendidikan yaitu mencetak manusia seutuhnya dengan menciptakan 
keseimbangan antara kecerdasan intelektual, kecerdasan spiritual, dan kecerdasan emosional (Purwanto, 2011:21). Sebagai manusia, tidak hanya mengandalkan intelektual maupun emosional saja akan tetapi juga membutuhkan sikap spiritual untuk membimbing akhlak dan membentuk kepribadian seorang manusia menjadi lebih baik (Ichsan, 2019b).

Oleh sebab itu, pendidikan seharusnya dilaksanakan dalam sebuah tempat atau wadah yang mendukung berlangsungnya pembelajaran dengan kondisi dan situasi yang kondusif serta memadai iklim belajar yang baik pula. Salah satu lembaga pendidikan di nusantara ini sangat banyak, salah satunya adalah di lembaga pendidikan pondok pesantren. Dilihat dari segi historisnya, lembaga pendidikan ini sudah ada sejak berdirinya negara ini dan menjadi lembaga pendidikan tertua yang berkembang dan sejalan dengan dunia pendidikan pada umumnya (Tohir, 2019:2). Pada dasarnya, pendidikan yang ada di dalam pondok pesantren meliputi pendidikan agama Islam, dakwah, pendidikan pengembangan kemasyarakatan dan pendidikan sejenisnya yang meliputi aspek agama. Karena itu, lembaga pondok pesantren mempunyai beberapa tujuan seperti memahami, menghayati, dan mengamalkan ajaran-ajaran agama Islam dan mencetak generasi kader-kader yang berkualitas dan mempunyai martabat yang tinggi (Ichsan, 2019a).

Pesantren merupakan lembaga pendidikan dan pengembangan masyarakat, lembaga pendidikan ini merupakan lembaga yang mandiri dan indigenous culture yang berakar di tengah-tengah pedesaan (Nafi', 2007:vii). Jika disandingkan dengan lembaga-lembaga pendidikan di Nusantara, maka pondok pesantren merupakan produk kebudayaan Nusantara yang indigenous yang dianggap sebuah pendidikan yang tertua di Nusantara. Dianggap paling tertua karena pendidikan di dalam pondok pesantren berbasis kepada masyarakat yang sudah berdiri sejak masuknya masyarakat Islam di Nusantara ini pada abad ke-13 (Masyhud, 2005:1).

Pondok pesantren tidak lepas dari santri karena keduanya merupakan subkultur (sub-culture) Islam di negara Indonesia dan menjadi penjaga keilmuan dan intelektual Islam yang disandarkan dari sumber aslinya yaitu AlQur'an dan Hadist. dalam sistem pembelajaran di pondok pesantren sangat dibutuhkan seorang pengajar atau yang sering disebut dengan ustaz dan ustazah karena mereka mempunyai peran yang sangat penting dalam pembelajaran di pesantren untuk menyampaikan nilai-nilai pendidikan yang ada di pesantren tersebut (Miftahurrohman et al., 2021).

Seorang ustaz di pondok pesantren dalam menyalurkan ilmu-ilmu keagamaan kepada santri-santrinya diperlukan sumber keilmuan yang sudah jelas (Yusuf, 2019). Hal ini seperti kitab-kitab kuning yang dikarang oleh ulamaulama terdahulu yang masih digunakan sampai saat ini atau yang lebih dikenal 
dengan sebutan kitab kuning. kitab-kitab kuning mempunyai ciri khas tersendiri yaitu ditulis menggunakan teks Arab, meskipun menggunakan teks Arab tidak semua kitab-kitab kuning menggunakan bahasa Arab melainkan menggunakan bahasa yang dipakai pengarang kitab tersebut dalam menyampaikan pembelajaran di daerah pengarang tinggal. Seperti halnya ulama-ulama yang ada di Indonesia yang menuliskan kitabnya menggunakan bahasa Indonesia dan bahasa Jawa.

Lembaga pendidikan pondok pesantren memiliki sistem pendidikan non formal atau sistem pendidikan klasik yang lebih dikenal dengan pondok pesantren salafiyah, dalam sistem pembelajarannya banyak menerapkan metode-metode klasik seperti sorogan, bandungan, dan wethon (Wahid, 1999:280). Sejalan dengan perkembangan zaman di mana lembaga pendidikan di Indonesia mulai melakukan perkembangan secara pesat, pondok pesantren tidak menutupi diri untuk mengadakan pembaharuan metode maupun teknik pelaksanaan pendidikan, meskipun tidak semua pesantren mau untuk membuka inovasi dan pembaharuan terhadap metode pembelajaran yang ada di pesantren tersebut (Afandi, 2019). Dalam hal ini, peneliti ingin menggali dan mengetahui lebih dalam tentang pelaksanaan dan metode pembelajaran kitab kuning yang ada di pondok pesantren, dalam hal ini peneliti menemukan beberapa masalah. Permasalahan itulah yang menjadi salah satu kendala dalam proses belajar kegiatan mengajar di pondok pesantren Wali Songo Wonolelo Pleret Bantul Yogyakarta.

Berdirinya pondok pesantren Wali Songo yang berada di daerah Wonolelo Pleret Bantul ini pertama kali dipimpin oleh KH Imam Baehaqi pada tahun 1990, kebanyakan santri yang tinggal di pondok pesntren ini datang dari berbagai luar daerah meskipun mayoritas santri kebanyakan berasal dari daerah lingkungan masyarakat sekitar pondok. Melihat sejarahnya pondok Wali Songo dulunya hanya tempat yang dipakai untuk menampung anak-anak dan remaja warga maysarakat yang ingin belajar agama, semakin banyaknya para pelajar dan atusias masyarakat yang ingin belajar agama maka berdirilah lembaga pendidikan pondok pesantren Wali Songo di Kalurahan Wonolelo Kepanewonan Pleret Kabupaten Bantul.

Sebagian santri yang belajar di pondok pesantren Wali Songo tidak hanya ditempati oleh para pelajar dari luar daerah saja, banyak dari mereka yang berasal dari daerah sekitar lingkungan pondok. Hal tersebut bisa disimpulkan bahwa santri di pondok pesantren Wali Songo tidak semuanya tinggal dalam pesantren, sebagian dari mereka berangkat dari rumah dan mengikuti beberapa kegiatan yang ada di pesantren. Santri ialah sebutan untuk siswa-siswa yang sedang belajar dan mendalami keilmuan agama di pondok pesantren. Biasanya santri tinggal dan menetap dalam pesantren atau asrama pondok yang sudah 
disediakan, namun banyak juga santri yang tidak bisa tinggal di asrama pesantren atau tempat yang sudah disediakan di pondok yang biasa diberi sesebutan dengan santri desa (santri nonmukim) (Khulusinniyah \& Wassalwa, 2017:244).

Melihat latar belakang di atas, santri desa yang tentunya berbeda-beda para santri yang ingin masuk ke pondok pesantren harus terlebih dahulu untuk membiasakan diri dengan tulisan-tulisan dan bahasa Arab. Latar belakang pendidikan mereka sebelumnya tidak semua berbasis keagamaan. Sebab yang akan mereka pelajari adalah materi-materi pendidikan yang berasal dari kitab kuning dan tentunya kitab tersebut menggunakan tulisan dan berbahasa Arab. Sistem tersebut yang mengharuskan para santri untuk membiasakan diri dengan tulisan-tulisan Arab supaya mereka dapat dengan mudah menerima dan memahami materi-materi yang nantinya akan disampaikan oleh ustaz atau ustazah. Sebagai pembiasaan, diperlukan berbagai proses pembelajaran yang efektif, dan kedisiplinan, dan kesabaran.

Banyak penelitian yang terdahulu yang terkait peningkatan kitab kuning bagi santri, tetapi sepanjang penelusuran peneliti belum ditemukan penelitian yang secara fokus membahasa peningkatan bacaan kitab kuning bagi santri desa di pesantren salaf. Dalam penelitian ini, peneliti sudah menelaah dari beberapa karya ilmiah, di antaranya: (1) Skripsi dari Marlina Dwi Astuti yang berjudul "Metode Sorogan terhadap Pembelajaran Kitab Kuning di Pondok Pesantren Fadlun Munalloh Desa Wonokromo Pleret Bantul” (Astuti, 2015). (2) Skripsi dari Dwi Maelani yang berjudul "Implementasi Metode Sorogan dalam Pembelajaran Kitab Kuning di Pondok Pesantren Al-Hidayah Purwojati Purwokerto" (Maelani, 2020). (3) Skripsi dari Lia Nurjanah yang berjudul "Efektifitas Penerapan Metode Sorogan terhadap Kemampuan Membaca Kitab Kuning di Pondok Al-Hikmah Bandar Lampung" (Janah, 2018). (4) Tesis atas nama Muhammad Ichwan Jamzuri yang berjudul "Penggunaan Metode Sorogan dalam Peningkatan Kemampuan Membaca Kitab Kuning di Pondok Pesantren Miftahul Ulum Rukti Sediyo Raman Utara Lampung Timur" (Jamzuri, 2018), dan (5) Skripsi dari Nor Hamidah yang berjudul "Penerepan Metode Sorogan pada Pembelajaran Kitab Kuning di Pondok Pesantren Yasin Muara Teweh" (Hamidah, 2017).

\section{Metode}

Penelitian ini adalah penelitian lapangan dengan bentuk pendekatan kualitatif-deskriptif, yaitu hasil yang di dapatkan berbentuk data deskriptif berupa lisan dari orang-orang atau teks kalimat tertulis dari objek yang sedang diamati. Penelitian dalam bentuk kualitatif berfokus kepada pengamatan manusia dalam suatu kawasan tertentu (Moleong, 2002:3). Untuk mendapatkan 
data yang jelas dan terpercaya, maka peneliti melakukan teknik pengumpulan data melalui a) Observasi, b) Wawancara, dan c) Dokumentasi. Sedangkan analisis data dalam penelitian ini menggunakan a) Reduksi data, b) Penyajian Data, dan c) Penarikan Kesimpulan (Sugiyono, 2017:264).

Tidak hanya itu, keabsahan data dari penelitian ini memakai teknik triangulasi, dengan proses sebagai berikut: a) Membanding-bandingkan data dari satu sumber ke sumber lain, b) Membandingkan hasil wawancara yang dilakukan secara terbuka dan tertutup, dan c) Menganalisa kegiatan wawancara dari berbagai sumber untuk disimpulkan serta diminta kesepakatan dengan sumber data (Sugiyono, 2017:274).

\section{Hasil dan Pembahasan}

\subsection{Upaya Peningkatan Bacaan Kitab Kuning dengan Metode Sorogan kepada Santri desa di Pesantren Wali Songo}

Salah satu upaya ustaz dalam meningkatkan pembelajaran santri tentang bacaan kitab kuning yaitu dengan menerapkan metode yang sesuai, dan sebagai cara untuk ustaz atau ustazah dalam menyampaikan materi-materi yang terkandung dalam kitab kuning secara maksimal. Metode pembelajaran kitab kuning menjadi salah satu strategi yang bisa dipergunakan untuk membantu proses belajar mengajar, sehingga materi tersampaikan kepada santri-santri secara maksimal (hasil wawancara dengan PU, 22 Juni 2021).

Penerapan metode pembelajaran yang sesuai dan efektif sangat diperlukan dalam mencapai tujuan dari pembelajaran. Metode yang diterapkan dalam sistem pembelajaran di pondok pesantren sangat banyak dan bermacam-macam, salah satunya yaitu menggunakan metode sorogan. Metode ini termasuk salah satu metode tradisional dikalangan pondok pesantren dalam pembelajaran kitab kuning. Tidak berbeda dengan pembelajaran kitab kuning yang digunakan para ustaz di pondok pesantren Wali Songo terhadap santri desa dalam upaya mengenalkan dan meningkatkan bacaan dari kitab-kitab kuning yang dipelajarinya (hasil wawancara dengan AN, 23 Juni 2021).

\section{Penggunaan Metode Sorogan}

Proses pembelajaran kitab kuning di pondok pesantren Wali Songo untuk kalangan santri desa dilaksanakan dimulai setelah jamaah sholat ashar bagi kelas 1-5, sedangkan untuk yang kelas 6 dimulai setelah sholat isya'. Akan tetapi, tidak semua kelas menerapkan metode sorogan dalam pembelajaran kitab kuning, hanya santri kelas 6 yang sudah menerapkan metode sorogan. Dikarenakan santri yang sudah menginjak kelas 6 
kebanyakan santri yang sudah mendekati usia remaja dan sudah bisa mencerna isi dari kitab-kitab kuning yang sudah diberikan oleh ustadnya (hasil wawancara dengan AN, 23 Juni 2021).

Adapun pelaksanaan penerapan metode Sorogan dalam proses pembelajaran kitab kuning di pondok pesantren Wali Songo terhadap santri desa dengan cara, santri membaca dan menjelaskan sedikit kitab yang sudah ditentukan sesuai dengan tingkatan masing-masing dihadapan ustaz, sedangkan ustaz yang mengajar bisa menyimak, memperhatikan, memberi arahan dan bimbingan yang diperlukan. Sehingga dengan menerapkan metode ini, memungkinkan seorang ustaz bisa mengontrol dan mengetahui kemampuan santri dalam menguasai dan membaca kitab kuning (hasil wawancara dengan AN, 23 Juni 2021).

Dengan adanya metode sorogan ini, kesulitan yang dihadapi oleh santri dalam mempelajari kitab kuning semakin terbantu dan menjadikan santri lebih cepat dalam mempelajari bacaan dari materi yang ada pada kitab kuning yang dipelajarinya. Sedangkan, ustaz yang mengajarkan akan lebih maksimal dalam mengontrol dan membimbing santrinya dalam mempelajari kitab-kitab kuning tersebut (hasil wawancara dengan FM, 20 Juli 2021).

Dapat diketahui bahwa upaya seorang ustaz dalam meningkatkan bacaan kitab kuning kepada santri desa dengan menerapkan metode sorogan pada santri desa tidak diterapkan kepada seluruh santri desa, hanya santri kelas 6 dan santri yang umurnya sudah remaja yang sudah mengikuti proses pembelajaran kitab kuning mengunakan metode sorogan. Dengan diterapkannya metode tersebut, santri desa sangat cepat peningkatannya dalam membaca dan memahami dari materimateri yang terkandung dalam kitab kuning yang dipelajarinya.

\section{Materi dalam Metode Sorogan}

Penggunaan metode sorogan pada materi yang dipelajari santri di pondok pesantren Wali Songo sangat banyak, kebanyakan menggunakan literatur kitab kuning, akan tetapi tidak semua dari materi yang diajarkan di pondok pesantren Wali Songo menggunakan metode sorogan. Seperti halnya yang diterapkan kepada santri desa, hanya menggunakan kitabkitab dasar saja yang dipergunakan dalam pembelajaran kitab kuning, tidak semuanya bisa diajarkan kepada santri desa, mengingat waktu yang digunakan sangat terbatas (hasil wawancara dengan WD, 2 Juni 2021). Metode sorogan yang diterapkan terhadap santri desa digunakan untuk beberapa materi, di antara materi yang menggunakan metode sorogan yaitu sebagai berikut: 
a. Tauhid dengan menggunakan kitab 'Aqidatul Awam

Kitab yang menerangkan tentang tauhid yang diterapkan dalam pembelajaran santri desa yaitu kitab Aqidatul Awam, bahasa dalam kitab Aqidatul Awam tidak terlalu sulit, kalimat berbahasa Arab dan artinya tidak menjadi satu, maka kitab tersebut dipergunakan ustaz untuk santri desa tahap awal.

b. Fikih dengan Menggunakan kitab Mabadi Fiqih

Tingkatan selanjutnya yaitu kitab Mabadi Fiqih. Kitab tersebut menerangkan tentang Fikih, kitab ini merupakan kitab tahap awal yang menerangkan tentang ilmu Fikih atau hukum-hukum Islam, membaca kitab ini harus mengetahui gramatika dan susunan bahasa Arab. Susunan kalimat dan keterngan dalam kitab ini berbeda dengan kitab Aqidatul Awam, kalimat dan murodnya tersusun menjadi satu bagian. Oleh sebab itu, santri harus membaca terlebih dahulu teks berbahasa Arab setelah itu diartikan sesuai dengan teks Arab yang dibacanya.

c. Akhlak dengan menggunakan Akhlaqul Banin

Tingkatan selanjutnya sekaligus tingkatan yang terakhir untuk santri desa yaitu kitab Akhlaqul Banin. Kitab Akhlaqul Banin adalah kitab yang menerangkan tentang perilaku santri dalam kehidupan sehari-hari. Dalam pembelajaran kitab tahapan ini, santri harus mengartikan sendiri isi dari kalimat-kalimat yang ada pada kitabnya sebelum di setorkan dan dibaca di hadapan ustaznya. Pada pertemuan sebelumnya, santri ketika maju akan dibacakan artinya terlebih dahulu oleh ustaznya, yang nantinya akan dijadikan bekal membaca pada pertemuan selanjutnya.

\subsection{Hasil Peningkatan Bacaan Kitab Kuning dengan Metode Sorogan kepada Santri desa di Pesantren Wali Songo}

Lembaga pendidikan pondok pesantren menjadi sarana pendidikan yang menekankan pelajaran agama Islam terutama dalam pembelajaran al-Qur'an dan kitab-kitab keagamaan. Salah satu tujuan adanya lembaga pondok pesntren secara khusus ialah mempersiapkan para santri yang ahli dalam membaca al-Qur'an dan Kitab kuning untuk menjadi orang yang alim dalam ilmu agama yang sudah diajarkan oleh guru-guru yang bersangkutan, serta diharakan bisa untuk diamalkan dalam kehidupan sehari-hari untuk dirinya dan bermanfaat untuk mayarakat (Tohir, 2019).

Pondok pesantren Wali Songo adalah sebagian dari lembaga pendidikan di Indonesaia yang memprioritaskan pembelajaran kitab kuning, agar santri mahir dalam membacanya. Pemilihan metode dalam penyampaian materi di pondok pesantren menduduki urutan ke dua 
setelah materi, karena metode dapat diartikan sebagai cara yang penting dalam pembelajaran untuk mencapai tujuan dalam penyampaian materi. Penggunaan metode memungkinkan proses pendidikan menjadi lebih bagus dan terarah, sehingga tujuan dari pendidikan dapat tercapai secara efektif dan efisien (Arif, 2002:82).

Peran ustaz atau guru sangat penting dalam faktor penggerak proses belajar mengajar, akan mendapatkan kesuksesan dalam pembelajaran dan menambah pengaruh kepada anak didik berkaitan erat dengan khasanah ilmu dan keluasan pemikiran, kayakinan yang tinggi di dalam jiwa akan risalah yang digendongya, kecintaannya kepada santrinya dan karena pemilihan terhadap metodologi yang tepat dan benar.

Di pondok pesantren Wali Songo, pemilihan metode sorogan sebagai bukti upaya untuk meningkatkan kemampuan santri dalam membaca AlQur'an dan Kitab kuning. Dengan penggunaan metode sorogan ini, menimbulkan hubungan di antara ustaz dengan santri lebih dekat, karena seorang ustdz dapat mengenal kemampuan pribadi santri secara individu (Djamarah, 2010:74). Dari gambaran tersebut, dapat diketahui bahwa metode sorogan membutuhkan keaktifan santri.

Di sini santri yang mengikuti kegiatan pembelajaran kitab yang menggukan metode sorogan harus lebih aktif dalam belajarnya, dikarenakan santri harus mempersiapkan dirinya sebelum maju dihadapan ustaznya untuk membaca kitab kuning, supaya dalam setoran bacaanya nanti supaya tidak banyak menemukan kesalahan. Pembelajaran kitab kuning sebagai materi pelajaran yang didasari dengan penguasaan teknik membacanya atau kaidah-kaidah dalam kosa kata bahasa Arab sebagai penunjang keemampuan membacanya.

Untuk mengetahui hasil dari penerapan metode sorogan dalam pembelajaran kitab kuning terhadap santri desa, maka peneliti melakukan observasi terhadap beberapa santri desa dalam membaca kitabnya dengan meminta bantuan dari salah satu ustaz yang mengampu metode sorgan ini, dengan melakukan observasi kepada santri yang sedang melangsungkan sorogan kitab Mabadi Fikih juz pertama dengan bab Toharoh (bersuci). Dari lima belas santri yang saya amati sebanyak sembilan santri yang baik dalam menguasai materi-materi yang sedang dikaji dan empat yang lainya bisa dikatakan cukup baik dan dua santri termasuk kurang baik dalam menguasai materi-materi yang di sorogkan. Adapun Indikator penilaian dan kriteria tingkat kemampuan membaca santri desa dalam pembelajaran kitab kuning sebagai berikut:

1) Ketepatan dalam membaca 
Ketepatan membaca memiliki urgensi yang penting bagi kehidupan manusia (Ichsan, 2018). Pada kategori ketepatan membaca ini, didasarkan atas ketentuan-ketentuan dalam membaca dan sesuai dengan aturan membacanya. Maksud ketepatan dalam membaca di sini yaitu seorang santri desa mampu membaca kitab kuning didasarkan atas kaidah-kaidah aturan membaca, di antaranya santri harus mengetahui dan menguasai kosa kata bahasa arab terlebih dahulu dan bisa menguasai kalimat beserta artinya.

Dari hasil observasi dan hasil tes lisan yang sudah dilakukan oleh peneliti dan dibantu oleh ustaz yang bersangkutan, bisa disimpulkan bahwa santri desa di pondok pesantren Wali Songo khususnya santri yang sudah mengikuti metode sorogan ini cukup bagus dalam ketepatan membaca kitab kuning. Dikarenakan kebanyakan santri desa sudah didasari dari keaktifan mereka dalam menyiapkan bacaan sebelum mereka maju kehadapan ustaznya.

2) Kepahaman mendalami isi bacaan kitab kuning

Aktivitas membaca tidaklah hanya sebatas membaca sebuah teks tertulis saja, melainkan membaca yang disertai dengan pemahaman isi bacaan teks tertulis tersebut, baik berupa ide-ide gagasan dan pokok pikiran yang dikehendaki oleh pengarang atau penulis teks tersebut. Maka dari itu, pembelajaran kitab kuning terhadap santri desa tidak hanya dalam soal membaca, akan tetapi juga harus memahami apa yang sudah dibaca dalam kitab kuning tersebut.

Melihat dari hasil tes di atas bisa ditangkap kesimpulannya bahwa santri desa di pondok pesantren Wali Songo sudah baik dalam memahami isi bacaan yang telah mereka baca pada kitab kuning. Hal ini tidak lepas dari diri mereka yang sudah tepat dalam membaca dan penguasaan mufradhat bahasa Arab dan bahasa Arab Pegon santri.

3) Bisa mengungkapkan bacaan

Santri desa yang belajar di pondok pesantren Wali Songo yang mampu dalam membaca kitab kuning sesuai dengan aturan bakunya tetapi mereka lemah dalam segi mengungkapkan isi dari kandungannya, atau sebaliknya itu bisa terjadi disebabkan oleh suatu hal tertentu, misalnya mereka hanya memahami akan tetapi tidak memiliki ketrampilan dalam membaca dan mengungkapkan kitab kuning dan lainnya.

Berdasarkan hasil observasi terhadap santri pada saat melangsungkan pembelajaran dapat dilihat bahwa dari 15 santri desa yang membaca kitab kuning tersebut ada 7 santri desa dalam membaca 
kitab kuning baik, ada 5 santri desa dalam segi membaca kitab kuning masuk kriteria cukup baik, dan ada 3 santri yang kurang baik dalam segi membaca kitab kuning.

Di sini terlihat bahwa santri desa yang mengikuti pemebelajaran kitab kuning melalui metode sorogan di pondok pesantren Wali Songo yang aktif dalam megekuti metode sorogan mereka bisa meningkatkan kemampuan mereka dari segi membaca kitab kuning, baik dari kriteria ketetapan membaca, kepahaman mendalami isi bacaan dan dapat mengungkapkan dari isi bacaan. Berdasarkan dari hasil observasi, pen eliti melihat ada beberapa dari sebagian santri yang kurang baik dalam membaca kitab kuning, hal ini dikarenakan mereka masih kurang aktif dalam mengikuti metode sorogan dan sering menyepelekan kesiapan mereka sebelum maju dihadapan ustaznya dan tentunya kurangnya semangat dalam belajar.

Penerapan metode sorogan dalam proses pembelajaran kitab kuning terhadap santri desa di pondok pesantren Wali Songo sangat efektif untuk diterapkan. Disebabkan metode sorogan ini santri desa ditekankan untuk selalu aktif dan kritis, juga menuntut kedisplinan dan ketekunan santri desa. Ketika penerapan metode sorogan ini berlangsung santri langsung bertatapan muka secara langsung dengan para ustaz yang sedang mengajarkan dan yang mengampu metode tersebut, sehingga para santri desa bisa mengetahui kemampuannya secara individu dan ustaznya dapat melihat dan mengukur sejauhmana kemampuan masing-masing santri, dan pasti berbeda hasilnya jika dibandingkan dengan hanya menerapkan metode lain seperti ceramah.

Maka dari itu, bisa disimpulkan bahwa dengan menerapkan metode sorogan bisa diketahui hasilnya, yaitu santri desa bisa meningkatkan kemampuan membaca kitab kuning. Dengan demikian, bisa dilihat bahwa santri desa di pondok pesantren Wali Songo dalam membaca kitab kuning seperti membaca isi kitab Mabadi Fikih yang sudah baik, meskipun ada beberapa dari santri desa yang masuk kriteria cukup atau masih kurang baik dalam segi membaca kitab kuning, memahami isinya, dan mengungkapkan isi kandungan yang telah dibacanya, karena dari merkea sendri terkadang masih kurang aktif dalam mengikuti metode sorogan, sebabnya dalam pembelajaran metode sorogan yang diutamakan yaitu keaktifan dan ketekunan murid atau santri, terkhusus bagi santri desa yang waktunya sangat terbatas mengikuti pembelajaran di pondok pesantren Wali Songo Pleret Bantul. 


\subsection{Faktor Pendorong dan Penghambat Peningkatan Bacaan Kitab Kuning bagi Santri Desa di Pondok Pesantren Wali Songo}

Proses pembelajaran dalam suatu lembaga pendidikan, salah satunya lembaga pendidikan pondok pesantren, pasti memiliki sebuah target dan pencapaian pada suatu keberhasilan dalam proses pendidikan yang diterapkan. Akan tetapi, semua itu tidak lepas dari sesuatu yang dilatarbelakangi dari beberapa faktor, baik itu yang memungkinkan mendorong atau mendukung sebuah proses ataupun dapat menghabat jalannya proses pembelajaran yang dijalankan.

Seorang santri dalam mencapai target dan pencapaian pada sebuah keberhasilan membaca kitab kuning pada lembaga pendidikan di pondok pesantren Wali Songo dalam menerapkan metode sorogan terhadap santri desa, juga dilatar belakangi oleh beberapa faktor, baik itu faktor pendukung ataupun faktor penghambat.

1) Faktor Pendukung

Berdasarkan pelaksanaan proses pembelajaran kitab kuning menggunakan metode sorogan, maka tidak jarang ditemukan faktorfaktor yang mendukung dan menghambat berlangsungnya sebuah proses penerapan metode sorogan. Faktor-faktor yang mendukung dan yang menghabat dalam proses kegiatan pembelajaran kitab kuning terhadap santri desa di pondok pesantren Wali Songo, tidak lepas dari beberapa aspek internal atau external, diantara aspek tersebut berkaitan dengan sarana dan prasarana, waktu, materi, santri, dan ustaz dalam proses pembelajaran kitab kuning terhadap santri desa di pondok pesantren Wali Songo (hasil wawancara dengan AN, 23 Juni 2021).

Faktor pendukung dalam proses meningkatkan bacaan kitab kuning terhadap santri desa melalui sorogan di pondok pesantren Wali Songo dalam segi faktor internal ini meliputi:

a) Minat santri desa untuk belajar membaca kitab kuning. Jika santri mempunyai minat yang kuat maka proses pembelajaran menjadi berhasil.

b) Keseriusan santri desa. Jika seorang murid mempunyai keseriusan dan kesungguhan yang tinggi maka santri tidak akan merasa terbebani.

c) Motivasi. Adanya motivasi santri sangat diperlukan sekali, dengan adanya motivasi santri dari dirinya sendiri maka kemauan santri dalam meningkatkan bacaannya semakin kuat. 
d) Keadaan fisik. apabila keadaan fisik dari santri dan ustaz dalam kondisi baik, dan tidak sedang ada masalah. Maka kegiatan pelaksanaan belajar mengajar kitab kuning akan berjalan efektif..

e) Kesungguhan ustaz. Jika ustaz yang mengjar bersungguh-sungguh membimbing dan mengarahkan santri desa, dan ustaz serius dalam melakukan persiapan, maka proses pembelajaran akan semakin efektif.

f) Kompetensi ustaz. Seorang pengajar dapat mempengaruhi efektifnya pembelajaran dan baiknya sebuah pelaksanaan pembelajaran, jika pengajar berkompenten maka pembelajaran pun berlangsung sangat baik (hasil wawancara dengan NA, 19 Juni 2021).

Selain faktor internal yang bisa mendukung keberhasilan pembelajaran membaca kitab kuning, ada pula faktor eksternal. Faktor eksternal di sini juga sangat mempengaruhi keberhasilan dalam proses pembelajaran membaca kitab kuning bagi santri desa. hal ini juga diperkuat oleh pendapat dari beberapa ustaz yang mengampu pembelajaran membaca kitab kuning terhadap santri desa, ketika peneliti melakukan wawancara, dan observasi dilapangan, diantara pendapat para ustaz sebagai berikut:

a) Peran Kyai. Figur seorang kyai di sini sangat berpengaruh, karena kyai selalu berperan dalam memberikan motivasi-motivasi kepada santri-santrinya dan juga pengajar untuk selalu semangat dan bersungguh-sungguh dalam memperjuangkan dan melestarikan ilmu agamanya Allah S.W.T.

b) Suasana lingkungan. Suasana di pondok pesantren Wali Songo sangat nyaman dan aman, cukup jauh dari pemukiman warga masyarakat dan tidak terganggu dengan aktivitas warga masyarakat.

c) Teman. Sosok teman ialah suatu faktor penting yang bisa mempengaruhi kesemangatan santri dalam keseriusan belajar membaca kitab kuning. Hal itu dikarenakan dengan adanya teman yang baik bisa saling berkerja sama dalam meningkatkan bacaan kitab kuning yang dipelajarinya bersama-sama.

d) Waktu. Pelaksanaan pembelajaran membaca kitab kuning dengan menggunakan metode sorogan cukup mempengaruhi, karena dengan waktu yang tepat akan lebih efektif dalam pembelajaran, karena dipondok pesantren Wali Songo diadakan setelah maggrib 
dan Isya', sehingga santri masih mempunyai jeda waktu untuk belajar setelah pulang dari sekolah.

2) Faktor Penghambat

Faktor penghambat dalam proses pelaksanaan kegiatan pembelajaran membaca kitab kuning bagi santri desa melalui penerapan metode sorogan di pondok pesantren Wali Songo Pleret Bantul, juga dipengaruhi oleh beberapa faktor internal dan eksternal.

Adapun faktor internal yang menghambat pembelajaran membaca kitab kuning bagi santri desa dengan menerapkan metode sorogan di pondok pesantren Wali Songo antara lain: waktu pelaksanaan pembelajaran yang terbatas, dan ditambah lagi jika santri datangnya terlambat. Tidak hanya itu, ada faktor lain yang bisa menghambat jalannya proses pembelajaran kitab kuning, yakni faktor permasalah dalam diri.

Sedangkan faktor eksternal yang dapat menghambat kelancaran pembelajaran membaca kitab kuning santri desa di pesantren ini adalah terkendala oleh sebuah acara yang ada di desa santri, dan waktu yang bertabrakan dengan kegiatan rutinan pondok (seperti manaqib, mujahadah, dan lain sebagainya), sehingga para ustaz meliburkan kegiatan proses pembelajaran. Tidak hanya itu, faktor lainnya adalah pengajar yang membantu pengajaran membaca kitab kuning sangat terbatas.

\section{Kesimpulan}

Peningkatkan bacaan kitab kuning terhadap santri desa di Pondok Pesantren Wali Songo Pleret Bantul adalah dengan menerapkan metode sorogan dan memberikan materi-materi yang sesuai dalam kemampuan santri. Penerapan metode sorogan bertujuan sebagai pendekatan dan keharmonisan antara ustaz dan santri. Hasil penerapan tersebit memiliki efektifitas yang sangat tinggi. Hal ini dapat diketahui dari hasil tes lisan membaca kitab kuning, dengan menyesuaikan indikator yang mencapai kriterian ketuntasan atau baiknya kualitas bacaan dan juga didasari dari hasil wawancara terhadap ustaz maupun santri desa yang menunjukan hasil yang sangat memuaskan dalam meningkatkan bacaan kitab kuning menggunakan metode sorogan terhadap santri desa.

\section{Daftar Pustaka}

Afandi, Z. (2019). Strategi Pendidikan Entrepreneurship di Pesantren AlMawaddah Kudus. Bisnis: Jurnal Bisnis Dan Manajemen Islam, 7(1). 
Arif, A. (2002). Pengantar Ilmu dan Metodologi Pendidikan Islam. Ciputat Press.

Astuti, M. D. (2015). Metode Sorogan terhadap Pembelajaran Kitab Kuning. UIN Sunan Kalijaga Yogyakarta.

Djamarah, S. B. (2010). Strategi Belajar Mengajar. PT Rineka Cipta.

Hamidah, N. (2017). Penerapan Metode Sorogan Pada Pembelajaran Kitab Kuning di Pondok Pesantyren Yasin Muara Teweh. IAIN Palangkaraya.

Ichsan, A. S. (2018). Gerakan Literasi Sekolah di Sekolah Islam (Sebuah Analisis Implementasi GLS Di MI Muhammadiyah Gunungkidul). Al-Bidayah: Jurnal Pendidikan Dasar Islam, 10(1), 69-88. https://doi.org/10.14421/ALBIDAYAH.V10I1.189

Ichsan, A. S. (2019a). Konstruksi Pendidikan Relasi Kiai dan Santri di Pondok Pesantren Lintang Songo Piyungan Yogyakarta (Sebuah Pendekatan Multidisipliner). Jurnal Darussalam; Jurnal Pendidikan, Komunikasi Dan Pemikiran Hukum Islam, XI(1).

Ichsan, A. S. (2019b). Revisiting the Value Education in the Field of Primary Education (A Study on Abdurrahman An-Nahlawi's Perspective). Elementary: Jurnal Ilmiah Pendidikan Dasar, https://doi.org/http://dx.doi.org/10.32332/elementary.v5i2.1643

Jamzuri, M. I. (2018). Penggunaan Metode Sorogan dalam Peningkatan kemampuan Membaca Kitab Kuning di Pondok Pesantren Miftahul Ulum Rukti Sediyo Raman Utara Lampung Timur. IAIN Metro Lampung.

Janah, N. (2018). Efektifitas Penerapan Metode Sorogan terhadap Kemampuan Membaca Kitab Kuning. UIN Raden Intan Lampung.

Khulusinniyah, \& Wassalwa, A. (2017). Reorientasi Nilai-Nilai Kepesantrenan Pada Santri kalong Pondok Salafiyah Syafi'iyah Sukerejo. JPPI, 1(2).

M. Dian Nafi'. (2007). Praksis Pembelajaran Pesantren. PT LKiS Pelangi Aksara.

Maelani, D. (2020). Implementasi Metode Sorogan dalam Pembelajaran Kitab Kuning. IAIN Purwokerto.

Masyhud, M. S. dkk. M. (2005). Managemen Pondok Pesantren. Diva Pustaka.

Miftahurrohman, M., Ichsan, A. S., \& Yunianta, R. D. (2021). Upaya Guru Al-Qur'an Hadis dalam Meningkatkan Hasil Belajar Siswa Kelas 2 MI Sananul Ula Piyungan Bantul Yogyakarta pada Masa Pandemi. QuranicEdu: Journal of Islamic Education, 1(1), 19-39. https://jurnalannur.ac.id/index.php/QuranicEdu/article/view/112

Moleong, L. J. (2002). Metodologi Penelitian Kualitatif. PT Remaja Rosdakarya. Purwanto, N. (2011). Ilmu Pendidikan Teoritis dan Praktis. Rosdakarya.

Sugiyono. (2017). Metode Penelitian kuantitatif, Kualitatif dan R\&D. Alfabeta. 
Tohir, K. (2019). Model Pendidikan Pesantren Salafi. Scopindo Media Pustaka.

Wahid, A. (1999). Pesantren Masa Depan. Pustaka Hidayah.

Yusuf, S. A. M. M. A. C. N. \& K. A. R. (2019). Tahfiz Teachers Ability in Teaching of the Subject Hifz Quran in Implementing Integrated Curriculum Tahfiz (KBT) Secondary Schools. International Journal of Academic Research in Business and Social Sciences, 9(5), 836 - 850. https://doi.org/10.6007/IJARBSS/v9i5/6010 